\title{
Pilot Study on the Effects of Partially Restored Riparian Plant Communities on Habitat Quality and Biodiversity along First-Order Tributaries of the Lower St. Johns River
}

\author{
Anthony M. Rossi $^{1 *}$, Daniel C. Moon ${ }^{1}$, Dale Casamatta ${ }^{1}$, Kelly Smith ${ }^{1}$, Christopher Bentzien ${ }^{1}$, Jason \\ McGregor $^{1}$, Alyson Norwich, \\ Emilie Perkerson $^{1}$, Ralph Perkerson ${ }^{1}, J_{0 a n n a}$ Savinon $^{1}$, Keith Stokes ${ }^{2}$, Dean Doebberfuhl ${ }^{3}$ \\ ${ }^{1}$ Department of Biology, University of North Florida, Jacksonville, USA \\ ${ }^{2}$ Department of Biology, University of South Florida, Tampa, USA \\ ${ }^{3}$ St. Johns Water Management District, Palatka, USA \\ E-mail:arossi@unf.edu \\ Received June 8, 2010; revised June 22, 2010; accepted June 30, 2010
}

\begin{abstract}
The St. Johns River is one of the premiere waterways in the southeastern United States, but it is increasingly affected by anthropogenic disturbances and influences such as excessive loading of nutrients. In the current pilot project, small native plant communities ("garden sites") were established along sections of riparian corridors of five first-order tributaries in residential-commercial areas that drain into the lower St. Johns River in north Florida. In addition, four "non-garden" (control) tributaries were monitored for comparison. Garden sites included five species native to the area; 20 plants of each species on both banks (200 total plants). These sites were used to assess the ability of partially restored riparian areas to ameliorate nutrient loading and water quality and determine their impact on local biodiversity in disturbed suburban drainage systems. Partially restored sites showed a significant reduction in both $\mathrm{NO}_{3}{ }^{-}$and $\mathrm{P}$ concentrations in both soil and water samples compared to control sites. For instance, soil $\mathrm{NO}_{3}^{-}$levels were reduced by $14 \%$ in garden sites, while water samples were 30\% lower. Moreover, both plant species richness and Shannon diversity (H') were significantly higher at partially restored sites, 33 and 19\% respectively, compared to control streams after two years. Garden sites also had significantly higher terrestrial and invertebrate diversity than non-restored tributaries. Intermittent patches of partially restored habitat along suburban riparian corridors may provide a practical cost-effective technique for improving ecosystem function, water quality and increasing biodiversity along these frequently disturbed lotic habitats. Trends detected in the current study may have general implications for riparian restoration and reduction of nutrient loading in these small tributaries and, ultimately, effect water quality of the lower St. Johns River basin.
\end{abstract}

Keywords: Riparian, Restoration, Biodiversity, Soil and Water Quality

\section{Introduction}

Florida's human population has increased dramatically over the last four decades; increasing from approximately 4.95 million in 1960 to ca. 19.7 million in 2010 which makes Florida the fourth most populous state behind only California, Texas and New York. Moreover, Florida's population has typically grown considerably faster than the overall U.S. population; for instance, Florida's population increased $14.2 \%$ for the eight-year period 2000-2008, while the overall U.S. population increased by only $7.8 \%$ (rates calculated using data from the U.S. Census Bureau 2009). This rapidly increasing human population is placing a great deal of stress on Florida's ecosystems, especially its watersheds, freshwater supply and coastal communities. As a result, riparian zones have become a major focus of watershed initiatives to improve degraded stream systems because alterations of these transitional ecotones can have significant effects on the aquatic ecosystems that they bor- 
der [1,2].

Natural tributaries are common in suburban and urban settings, but they are often highly disturbed (many stream banks are maintained by regular mowing), eutrophic from excessive inorganic nutrient loading and have reduced plant diversity, especially of shrubs and trees [1]. Substantial research has found that high levels of nutrients in lotic systems can significantly affect the ecology of recipient rivers, lakes and estuaries [3]. Of special concern are levels of inorganic nitrogen and phosphorous which are the two nutrients most often associated with algal blooms, although the strength of the relationship is often affected by other environmental factors such as irradiance and water temperature [4-9]. In addition, the relative strength of top-down (primarily invertebrate grazers) and bottom-up (nutrients) factors in limiting phytoplankton abundance and/or diversity vary temporally. For instance, Vanni and Temte [10] found that grazing by zooplankton was more important in limiting phytoplankton populations in a lake during the spring, but nutrient limitation was more important in the summer.

Removal of native vegetation, especially trees and shrubs, while facilitating access and maintenance of urban streams, can greatly affect ecosystem functions including in-stream processing of nutrients and pollutants $[3,11,12]$. Loss of riparian forest has been found to influence stream parameters such as light fluxes, temperature, and nutrient levels [6,12-14]. For instance, Peterjohn and Correll [3] calculated that surface water that had filtered across approximately $50 \mathrm{~m}$ of riparian forest removed about $45 \mathrm{~kg} / \mathrm{ha}$ of nitrate nitrogen per year; additionally, riparian forest sequestered more nutrients than nearby cropland. Wahl et al. [14] found outflow of inorganic nitrogen from urbanized deforested stream was more than twice that of a forested riparian watershed. Fluctuations in light levels can also influence algal abundance and community composition. Sabater et al. [6] found that open nutrient-rich tributaries with warmer temperatures had significantly higher levels of algal biomass than shaded nutrient-poor streams. These results are consistent with other studies that have found interactions of various degrees between light levels, temperature and nutrient levels $[5,9,15,16]$.

Transitional zones such as wetlands and riparian ecotones also provide important habitat for invertebrate communities and provide refugia for juvenile fish and amphibians. According to Richardson et al. [11], riparian management was initially developed to protect and improve fish habitat. Loss of tree and shrub communities, which is common along urban and suburban tributaries, will result in decreased leaf litter. Reduced leaf litter has been associated with decreased detritivore populations, which leads in turn to decreased abundance of aquatic and terrestrial insect prey available for fish [17]. In addition, Renöfält and Nilsson [18] found that when they experimentally disturbed riparian vegetation by cutting along a river in Sweden, plant species composition was unaffected, but species richness was reduced. Reduction of vegetation in riparian and marine habitats may have cascading effects on higher trophic levels. For instance, arthropod abundance was significantly higher in riparian sites that contained supralittorial vegetation compared to a site in which the vegetation had been removed [2].

Riparian reforestation projects, incorporating native shrubs, forbs and other understory species, have the potential to ameliorate nutrient loading and reduce rates of species loss in urbanized areas. Riparian strips also serve as corridors for both plants and wildlife by facilitating the movement of colonizing individuals between suitable patches of habitat as well as gene flow among otherwise isolated populations $[12,19]$. Restoration projects are becoming increasingly common and provide important opportunities to conduct research on the effects of scale on basic ecological principles such as nutrient cycling and species-area relationships [20,21]. It has been suggested that riparian forest widths of 30-100 m may be necessary to provide sufficient habitat to maintain pre-logging densities of some wildlife [11]. The current study suggests that partial restoration of native vegetation of much smaller fragmented patches along first-order tributaries of the St. Johns may provide local benefits to the watershed including reduction of nutrients associated with eutrophication and algal blooms and modest increases in biodiversity over a relatively short time.

The St. Johns River is Florida's largest river and it is an important natural and cultural resource for central and north Florida. Although it is a primary source of fresh water for Florida and it was designated as a National Heritage River in 2002, high levels of inorganic fertilizers enter the watershed from commercial and residential areas, significantly reducing water quality [22]. Continued loading of inorganic nitrogen and phosphorous is likely facilitated by typical urban riparian management techniques such as tree removal and regular mowing, which are designed to facilitate maintenance and rapid removal of large volumes of water after storms, reduces the structure and complexity of the ecosystem. This increase in nutrient enrichment has resulted in frequent and extensive algal blooms in the river over the past ten years. Algal blooms often release toxins into the water column which may cause irritation of the skin and eyes, respiratory problems and even paralyze or kill fish and deplete oxygen levels [22]. In the current study we created small patches of partially restored native plant communities along several small tributaries in the lower St. Johns 
River basin to investigate their effects on local water quality and biodiversity. Biodiversity was assessed across multiple taxa including algae, plants, as well as both aquatic and terrestrial invertebrates. Lastly, the ability of these semi-restored patches of native plant communities to ameliorate nutrient concentrations in both the soil and water was compared to non-manipulated urban tributaries.

\section{Materials and Methods}

\subsection{Study Sites}

This project was conducted in Duval County, Florida

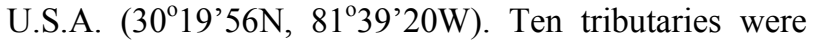
selected for the study using four primary criteria: 1) release into the St. Johns River; 2) first-order stream; 3) disturbed ecosystem (from human activities, e.g. mowing); and 4) access to sites (e.g. government maintained riparian zones, etc.). Owing to difficulty in accessing one site from private property, it was dropped from the study; the remaining nine sites were randomly placed into either a non-manipulated control group $(n=4)$ or treatment group $(\mathrm{n}=5)$. The sites (and abbreviations used hereafter) included in the control group were: "Carriage House" (C), "Stetson" (S), "Oak Bluff" (OB), and "Old River" (OR), while the treatment group included: "Old Kings" (OK), "Praver" (P), "Kingsley" (K), "Acosta" (A) and "Lowes" (L) (Figure 1). Prior to initiating treatments, depth and width of each tributary were measured; no differences (results not shown) were found for either parameter for treated vs. control streams (mean $\pm \mathrm{sd}$ were: width $=260.8 \pm 133.3 \mathrm{~cm}$ and depth $=23.9 \pm 17.6$ $\mathrm{cm}$ ). Experimental plots (see below) were established at treatment sites and transects for determination of plant and terrestrial invertebrate communities were conducted at all sites from spring 2006 through 2008.

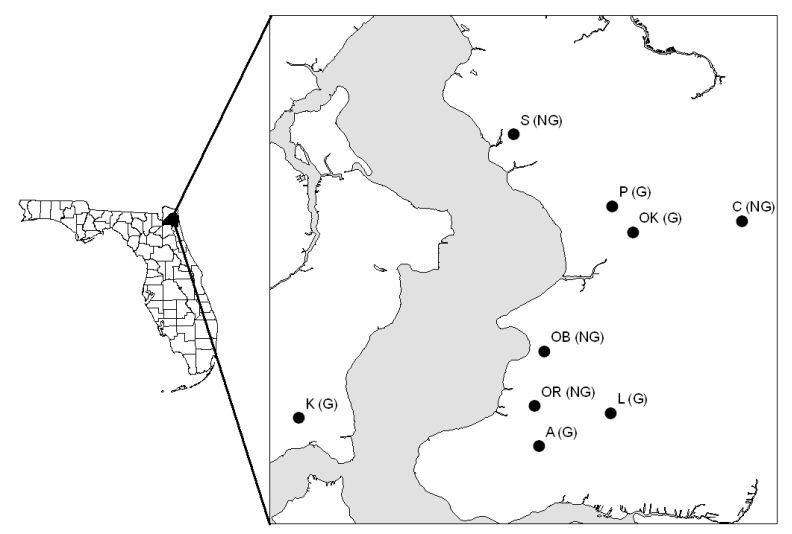

Figure 1. Study sites from Jacksonville, Duval County, Florida; "NG" refers to control sites and " $G$ " represents garden (or partially restored) sites (see text for details).

\subsection{Experimental Plots}

Along the banks of the five tributaries chosen for the treatment group, two experimental plots, each measuring $3 \times 9.5 \mathrm{~m}$, were established with the long dimension parallel to the water. Each plot was supplemented with 20 individuals of five plant species on each bank of the tributaries (200 total plants per tributary) that are native to riparian areas of northeast Florida (referred to as "garden sites"). Native plant species were chosen for the study to maximize structural complexity of the partially restored riparian sites and included (from the waterway and moving up the stream bank to higher elevation): Pontederia cordata (pickerelweed), Canna flaccida (golden Canna), Panicum hemotomon (maidencane grass), Itea virginica (Virginia willow) and Betula nigra (river birch). Along the banks of each garden site, plants were planted in 5 rows x 20 columns as described above. Plants were allowed a 3-month "grow in" period prior to sampling. All plants were acquired from a local grower (Native and Unusual Plants, Duval County, Florida) in 2006 and cultured for approximately six months under standardized conditions in the greenhouse at University of North Florida prior to use in the study. In addition, non-native plant species were identified and manually removed from experimental plots as needed. Similarly, plots were established at the four control sites and plant transects were established to serve as reference for the experimental sites.

\subsection{Plant Sampling}

At each site, six 15-m parallel transects were established (three on either side of the tributary). Although transects ran perpendicularly to the tributary, they were established in the center of each stream in an effort to sample aquatic and semi-aquatic species. The ends of transects were marked using wooden stakes and survey flags and the end points were recorded using hand-held GPS receivers. All plant species present within $0.5 \mathrm{~m}$ of the midline of each transect were recorded (creating belt transects $1 \mathrm{~m}$ wide). Species richness was recorded at each sampling date and plant diversity was assessed using both the Simpson index $\left(D_{s}\right)$ and the Shannon index (H') because, unlike $D_{s}$, it is sensitive to rare species such as Orontium aquaticum (golden club), which are likely to occur in small isolated pockets along some tributaries.

\subsection{Soil and Water Chemistry}

Soil samples were analyzed quarterly from March 2007 through September 2008. Samples were collected along 
the permanent transects at each site approximately $1 \mathrm{~m}$ up the bank from the edge of each tributary. A 1-cm diameter by $10-\mathrm{cm}$ deep core was collected in each sub-sample, and soil was sieved and homogenized prior to analysis. Four samples were taken at each garden site and six at each non-garden site on each sampling date. Samples from each transect within a site were analyzed separately, but the data were then averaged to yield a single site value for each variable per sampling date. Soil was analyzed using LaMotte Soil Test Kit Model STH-14 to determine $\mathrm{pH}$, nitrate nitrogen $\left(\mathrm{NO}_{3}{ }^{-}\right)\left(\mathrm{kg}^{\cdot} \mathrm{ha}^{-1}\right)$, nitrite nitrogen $\left(\mathrm{NO}_{2}^{-}\right)\left(\mathrm{mgkg}^{-1}\right)$, phosphorous $(\mathrm{P})\left(\mathrm{kgha}^{-1}\right)$, and potassium $(\mathrm{K})\left(\mathrm{kgha}^{-1}\right)$ levels. Levels of each soil variable were quantified using a LaMotte Smart2 colorimeter calibrated with a standard curve. Standard curves were generated by making artificial "soil", which consisted of sterile, non-nutritive builder's sand mixed with known concentrations of each chemical. The artificial soils were then run through the test kit extraction procedures and quantified using the colorimeter.

Physical and chemical parameters of the streams were recorded $1 \mathrm{~m}$ downstream from transects at each site. Chemical parameters included conductivity $(\mu \mathrm{S})$, salinity (ppt) and $\mathrm{pH}$ (measured with an IQ Scientific Instruments model IQ170, Carlsbad, $\mathrm{CA})$, and nitrate $\left(\mathrm{NO}_{3}{ }^{-}\right)$ and orthophosphate $\left(\mathrm{PO}_{4}{ }^{3-}\right)$ were measured using a LaMotte Smart2 colorimeter (LaMotte, Chestertown, MD). Physical parameters measured included stream width, depth and temperature. Biological parameters included percent algal coverage (measured by employing a $28-\mathrm{cm}^{2}$ sampling grid and estimated percent cover) and chlorophyll $a$ (measured using a Turner Scientific TD7200-000 fluorometer, Sunnyvale, CA). Ash-free dry mass (AFDM) was determined following standard protocols [sensu 23].

\subsection{Aquatic Macroinvertebrates and Terrestrial Arthropods}

Aquatic macroinvertebrates were collected in July, August and September of 2006, and then quarterly from September 2006 through September $20081 \mathrm{~m}$ downstream from site transects. Invertebrates were collected using a D-frame net (500 micron mesh) and round Hester-Dendy 14 plate sampler (total sampling area $0.13 \mathrm{~m}^{2}$ ). At each site on each date, 10 sweeps were performed and one round Hester-Dendy sampler was deployed. Hester-Dendy samplers were removed after fourteen days. All invertebrates were identified to species using a stereomicroscope. Terrestrial arthropod samples were collected at the same locations along plant transects from which soil samples were taken. Samples were collected monthly from July through September 2006, and then quarterly from September 2006 through September 2008 at each site. Arthropods were collected using a sweep net, with six non-consecutive sweeps conducted at each site on each date. Arthropods were also collected using 12.7 x $7.62 \mathrm{~cm}$ sticky traps placed at the height of the understory foliage. Sticky traps were placed at the same locations from which soil samples were taken and they were collected after one week in the field. All samples collected in the field were brought back to the lab and identified to species using a stereomicroscope.

\subsection{Algal Sampling}

Algal samples were collected from February 2007-August 2008 (19 sampling trips in total). Algal samples were collected downstream from transects at 1-m intervals determined randomly using a ten-sided die. Algae were collected by placing a three $\mathrm{cm}$ ring over the substrate and removing the associated algae using a turkey-baster. Samples were collected in triplicate, pooled to decrease site heterogeneity and preserved in $2.5 \%$ buffered glutaraldehyde. These samples were sub-divided into two aliquots destined for: 1) algal identification and 2) ash-free dry mass (AFDM). Identification of all algae was performed using an Olympus BX40 light microscope at 400x magnification using a Palmer-Maloney counting chamber (Wildco Wildlife Supply, Buffalo, NY). At least three subsamples were prepared from each sample and 400 cells enumerated. Identifications followed Geitler [24], Prescott [25], Komárek \& Anagnostidis [26,27], with taxonomy updated as necessary [28].

\subsection{Data Analysis}

For all analyses, subsamples within sites were averaged prior to analysis, and sites were used as replicates. Soil and water chemistry data were analyzed using repeated measures ANOVA. Diversity of algae, plants, aquatic invertebrates, and terrestrial arthropods was determined using species richness, Simpson's diversity index and the Shannon index. Simpson's index of diversity $\left(D_{s}\right)$ was calculated by $D_{s}=1-\sum n_{i}\left(n_{i}-1\right) / N(N-1)$, where $n_{i}$ is the number of individuals in each species and $N$ is the total number of individuals in the sample. Shannon's diversity index $\left(H^{\prime}\right)$ was calculated by $H^{\prime}=-\Sigma\left[\left(p_{i}\right)\left(\ln p_{i}\right)\right]$, where $p_{i}$ is the proportional abundance of individuals in each species. For plants, aquatic invertebrates, and terrestrial arthropods, analyses were based on numbers of individuals. Plant species used to create the experimental gardens were not included in diversity calculations. For algae, diversity analyses were performed using both cell counts and biovolumes. In the analysis, biovolumes could not be normalized through any transformation, so only the re- 
sults using cell counts are reported. Results from analyses using biovolumes did, however, produce the same trends. Plant and invertebrate data were analyzed using ANCOVA with initial (2006) values used as the covariate and final (2008) data as the dependent variable. Algal diversity was analyzed using repeated measures ANOVA. Finally, Pearson correlation matrices were generated for aquatic (water chemistry, algal and invertebrate diversity) and terrestrial (soil chemistry, plant and invertebrate diversity) data to further examine relationships among response variables. Bonferroni corrections were applied to $P$ values, but because of the number of variables included, almost all $\mathrm{P}$ values were non-significant after correction. Therefore, uncorrected $\mathrm{P}$ values are reported with an indication of which values remained significant following Bonferroni correction. Normality and homoscedasticity were tested using the Shapiro-Wilk and Bartlett's tests, respectively, and data were transformed when necessary for parametric analysis. All statistical tests were performed using Systat 11 .

\section{Results and Discussions}

\subsection{Effects on Soil and Water Chemistry}

Sites with partially restored plant communities had a significant (or marginally significant) effect on several soil and water parameters (Tables 1,2). Garden sites significantly affected levels of soil nitrate and $\mathrm{pH}\left(\mathrm{F}_{1,7}=\right.$ $6.065, \mathrm{P}=0.043 ; \mathrm{F}_{1,7}=4.830, \mathrm{P}=0.064$ respectively) (Table 1). While some parameters such as water temperature, etc. exhibited a significant time effect (data not shown), which largely correlated with seasonal variation, several parameters also demonstrated significant time $\mathrm{x}$ treatment interactions. For instance, although we found no significant effect of treatment on soil phosphorous concentrations $\left(\mathrm{F}_{1,7}=0.509, \mathrm{P}=0.599\right)$, this result is misleading because the garden sites, which had initial phosphorous levels of approximately twice that of control sites, were approximately $15 \%$ lower than non-garden sites by the end of the study (Figure 2). Phosphorous concentrations did not change in control sites over the course of the study, but they decreased rapidly at garden sites, which produced a highly significant time $\left(\mathrm{F}_{6,42}=12.187, \mathrm{P}<0.001\right)$ and time $\mathrm{x}$ treatment interaction $\left(\mathrm{F}_{6,42}=5.283, \mathrm{P}=0.003\right)$. Concentrations of these nutrients in the water were also significantly lower in tributaries with partially restored plant communities which resulted in a significant treatment effect for nitrate $\left(\mathrm{F}_{1,7}=7.080, \mathrm{P}=0.032\right)$ and time $\mathrm{x}$ treatment interaction for phosphorous $\left(\mathrm{F}_{13,91}=2.481, \mathrm{P}=0.017\right)$ (Figures 2,3).
Table 1. Effects of treatment on soil chemistry and biodiversity. All values are mean \pm sem; sample sizes are in parentheses. For each parameter, means followed by different letters have a significant treatment effect at $p=0.05$; parameters followed by an “†” indicates a $p<0.07$; those followed by an “*” have a significant time $x$ treatment interaction (see text and additional figures).

\begin{tabular}{|c|c|c|}
\hline Parameter & $\begin{array}{c}\text { Garden sites } \\
(\mathrm{n}=5)\end{array}$ & $\begin{array}{c}\text { Non-garden sites } \\
(\mathrm{n}=4)\end{array}$ \\
\hline $\mathrm{pH}^{*}$ & $6.7 \pm 0.08^{\mathrm{a}}$ & $5.9 \pm 0.04^{\mathrm{a}}$ \\
\hline Nitrate nitrogen $(\mathrm{kg} / \mathrm{ha})$ & $9.8 \pm 1.1^{\mathrm{a}}$ & $11.4 \pm .2 .2^{\mathrm{b}}$ \\
\hline Ammonium (ppm) & $2.8 \pm 0.07^{\mathrm{a}}$ & $3.1 \pm 0.17^{\mathrm{a}}$ \\
\hline Phosphorous (kg/ha)* & $81.9 \pm 14.9^{\mathrm{a}}$ & $60.5 \pm 3.6^{\mathrm{a}}$ \\
\hline Plant species richness & $41.2 \pm 2.8^{\mathrm{a}}$ & $27.2 \pm 5.1^{\mathrm{b}}$ \\
\hline Plant Simpson's $\left[\mathrm{D}_{\mathrm{s}}\right]$ & $0.92 \pm 0.07^{\mathrm{a}}$ & $0.89 \pm 0.06^{\mathrm{a}}$ \\
\hline Plant Shannon's [H'] & $1.47 \pm 0.97^{\mathrm{a}}$ & $1.23 \pm 0.14^{\mathrm{b}}$ \\
\hline Terrestrial invert species richness $\dagger$ & $77.6 \pm 6.9^{\mathrm{a}}$ & $57.0 \pm 10.8^{\mathrm{a}}$ \\
\hline Terrestrial invert Simpson's $\left[D_{s}\right]$ & $0.71 \pm 0.07^{\mathrm{a}}$ & $0.64 \pm 0.09^{\mathrm{a}}$ \\
\hline Terrestrial invert Shannon's [H'] & $1.45 \pm 0.11^{\mathrm{a}}$ & $0.99 \pm 0.14^{\mathrm{b}}$ \\
\hline Aquatic invert species richness $\dagger$ & $17.0 \pm 3.7^{\mathrm{a}}$ & $15.2 \pm 3.4^{\mathrm{a}}$ \\
\hline Aquatic invert Simpson's $\left[D_{s}\right]$ & $0.53 \pm 0.07^{\mathrm{a}}$ & $0.51 \pm 0.01^{\mathrm{b}}$ \\
\hline Aquatic invert Shannon's [H'] & $1.46 \pm 0.16^{\mathrm{a}}$ & $1.43 \pm 0.17^{\mathrm{a}}$ \\
\hline
\end{tabular}

Table 2. Effects of treatment on water quality, stream characteristics and algal biodiversity. All values are mean \pm sem; sample sizes are in parentheses. For each parameter, means followed by different letters have a significant treatment effect at $\mathbf{p}=\mathbf{0 . 0 5}$; parameters followed by an “*” have a significant time $x$ treatment interaction (see text and additional figures).

\begin{tabular}{lll}
\hline Parameter & $\begin{array}{l}\text { Garden sites } \\
(\mathrm{n}=5)\end{array}$ & $\begin{array}{l}\text { Non-garden sites } \\
(\mathrm{n}=4)\end{array}$ \\
\hline $\mathrm{pH}$ & $7.2 \pm 0.1^{\mathrm{a}}$ & $7.3 \pm 0.1^{\mathrm{a}}$ \\
Conductivity $(\mu \mathrm{S})$ & $28.8 \pm 7.0^{\mathrm{a}}$ & $51.6 \pm 12.5^{\mathrm{a}}$ \\
Depth (cm) & $14.8 \pm 1.0^{\mathrm{a}}$ & $22.8 \pm 1.5^{\mathrm{a}}$ \\
Width (cm) & $230.3 \pm 8.3^{\mathrm{a}}$ & $284.2 \pm 11.5^{\mathrm{a}}$ \\
Temperature $\left({ }^{\circ} \mathrm{C}\right)$ & $20.8 \pm 1.2^{\mathrm{a}}$ & $21.3 \pm 1.2^{\mathrm{a}}$ \\
Ash free dry mass $(\mathrm{g})$ & $0.02 \pm 0.003^{\mathrm{a}}$ & $0.02 \pm 0.004^{\mathrm{a}}$ \\
Nitrate nitrogen $(\mathrm{ppm})$ & $0.14 \pm 0.01^{\mathrm{a}}$ & $0.20 \pm 0.03^{\mathrm{b}}$ \\
Phosphate $(\mu \mathrm{g} / \mathrm{L})^{*}$ & $0.31 \pm 0.04^{\mathrm{a}}$ & $0.26 \pm 0.04^{\mathrm{a}}$ \\
Salinity $(\mathrm{ppt})$ & $0.16 \pm 0.01^{\mathrm{a}}$ & $0.16 \pm 0.01^{\mathrm{a}}$ \\
TDS (ppm) & $168.9 \pm 3.5^{\mathrm{a}}$ & $166.5 \pm 6.3^{\mathrm{a}}$ \\
Chlorophyll a $(\mu / \mathrm{L})$ & $6.9 \pm 1.3^{\mathrm{a}}$ & $12.7 \pm 3.1^{\mathrm{a}}$ \\
Macroalgae $(\%)$ & $0.04 \pm 0.03^{\mathrm{a}}$ & $8.0 \pm 2.29^{\mathrm{b}}$ \\
Algal species richness & $10.2 \pm 0.4^{\mathrm{a}}$ & $10.2 \pm 0.5^{\mathrm{a}}$ \\
Algal Simpson's $\left[\mathrm{D}_{\mathrm{s}}\right]($ cell counts) & $0.61 \pm 0.03^{\mathrm{a}}$ & $0.49 \pm 0.03^{\mathrm{a}}$ \\
Algal Simpson's $\left[\mathrm{D}_{\mathrm{s}}\right]($ biovolume) & $0.66 \pm 0.03^{\mathrm{a}}$ & $0.65 \pm 0.02^{\mathrm{a}}$ \\
Algal Shannon's $\left[\mathrm{H}^{\prime}\right]^{*}($ cell counts $)$ & $1.31 \pm 0.08^{\mathrm{a}}$ & $1.02 \pm 0.06^{\mathrm{a}}$ \\
Algal Shannon's [H'] (biovolume) & $1.42 \pm 0.07^{\mathrm{a}}$ & $1.40 \pm 0.06^{\mathrm{a}}$ \\
\hline & & \\
\hline
\end{tabular}



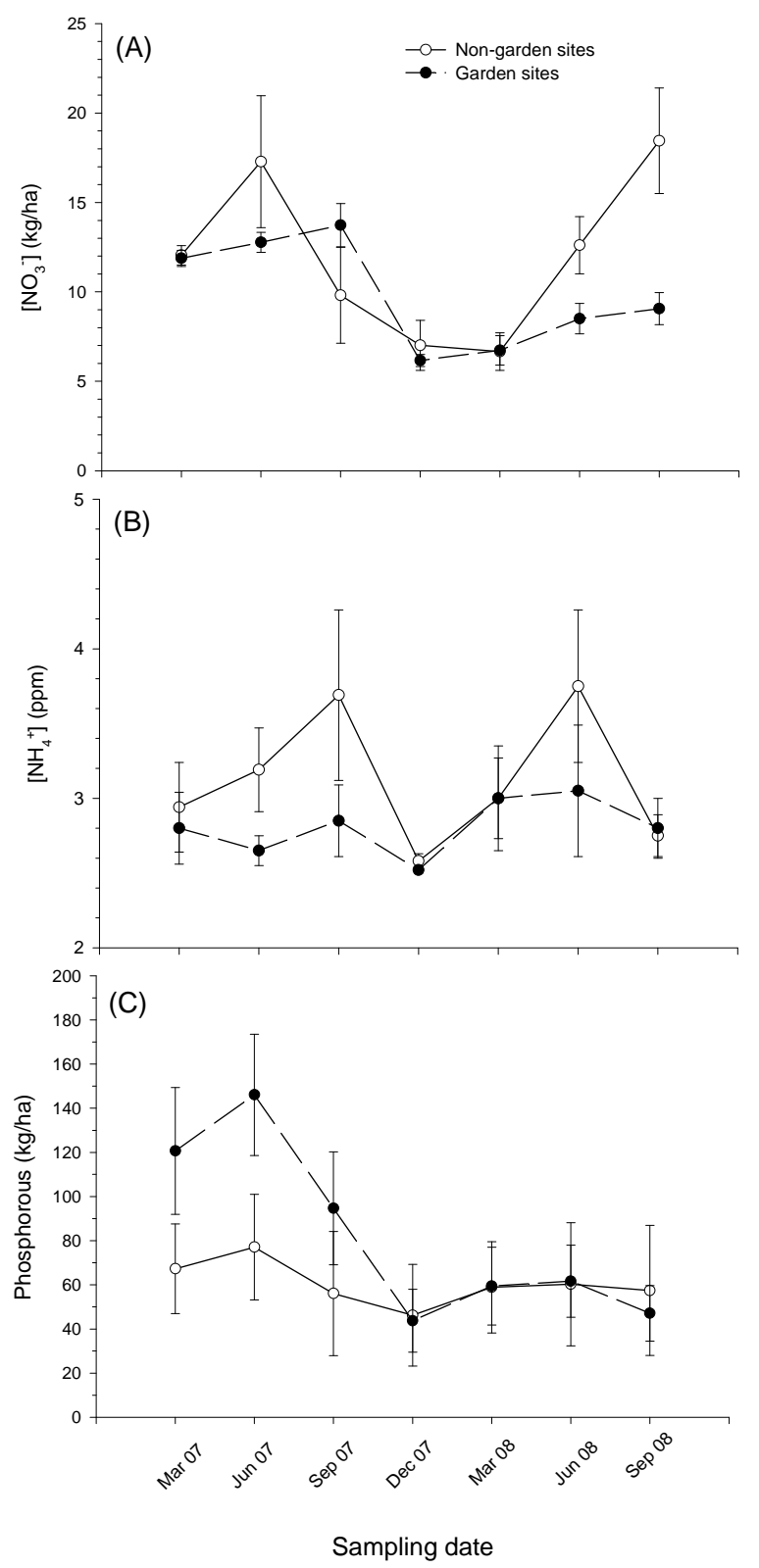

Figure 2.Comparison of soil parameters between garden and non-garden (= control) riparian sites; (A) pH, (B) $\left[\mathrm{NO}_{3}{ }^{-}\right]$ (kg/ha), and (C) Phosphorous (kg/ha). Values are mean \pm sem.

\subsection{Algal, Plant and Invertebrate Diversity}

After two years, tributaries with partially restored riparian plant communities had significantly higher plant diversity compared to non-manipulated control sites. Plant richness was $50 \%$ greater at restored sites compared to control sites (even after excluding the five species used to create the riparian gardens from the analysis; $F_{1,6}=$ $8.135, \mathrm{P}=0.029)$. While plant Simpson index $\left(\mathrm{D}_{\mathrm{s}}\right)$ was
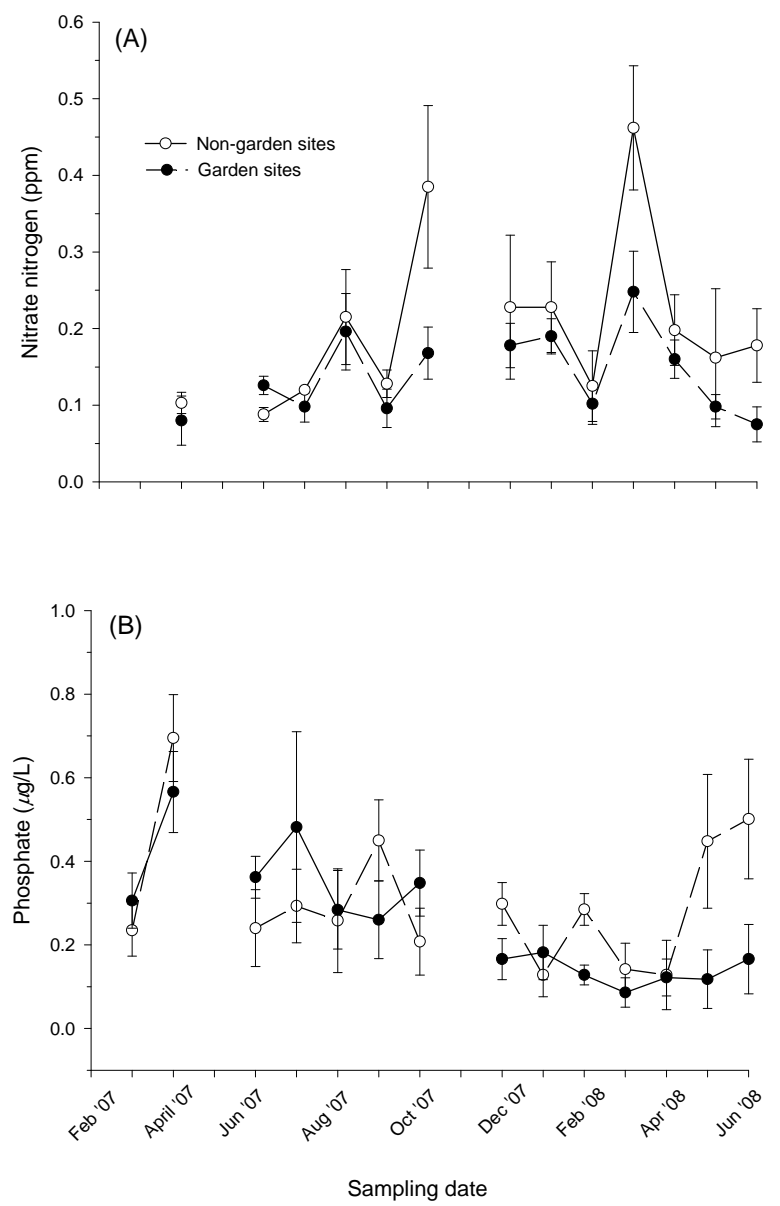

Figure 3. Comparison of aquatic levels of nitrate and phosphate between garden and non-garden (= control) sites; (A) nitrate nitrogen (ppm) and (B) phosphate $(\mu \mathrm{g} / \mathrm{L})$. Values are mean \pm sem.

also higher for garden sites this difference was not significant $\left(\mathrm{F}_{1,6}=0.725, \mathrm{P}=0.427\right)$; however, plant Shannon index $\left(\mathrm{H}^{\prime}\right)$ was significantly higher for partially restored sites $\left(\mathrm{F}_{1,6}=8.127, \mathrm{P}=0.029\right)$ (Table 1 and Figure 4). The difference in significance between the two indices is the result of how each is calculated; $D_{s}$ is a dominance index (i.e. weighted toward the most abundant members of the community), while $H^{\prime}$ is much more sensitive to rare species. Because plant communities at both garden and control sites were primarily populated by a few dominant species such as Acer rubrum (red maple), Toxicodendron radicans (poison ivy), Woodwardia areolata (netted-chain fern), etc. (data not shown), there was no significant effect on $\mathrm{D}_{\mathrm{s}}$. However, H' was significantly greater for partially restored sites because they included several rare species that only became established after the experiment was initiated.

A total of 17,789 terrestrial arthropods from 76 families and 221 species were collected. Only 647 aquatic 
invertebrates were collected, representing 37 families and 89 species. For both groups, however, species loading curves (not shown) indicated that sampling effort was adequate for detecting the true diversity of each site. Both terrestrial and aquatic macroinvertebrate communities were affected by establishment of experimental gardens. For terrestrial arthropods, mean species richness increased by $36 \%$ (from 57.0 to 77.6 ) at sites with experimental gardens, and this difference tended toward significance $\left(\mathrm{F}_{1,6}=5.460, \mathrm{P}=0.058\right)$. Garden sites exhibited increased representation of rare species as evidenced by a significant $\left(\mathrm{F}_{1,6}=10.389, \mathrm{P}=0.018\right)$ increase in Shannon index values (Table 1, Figure 4). Although Simpson's Diversity index $\left(D_{s}\right)$ values were slightly higher for garden sites than non-garden sites (0.92 vs. 0.89, Table 1 and Figure 4), this difference, similar to the result for plant $\mathrm{D}_{\mathrm{s}}$, was not significant $\left(\mathrm{F}_{1,6}\right.$ $=.667, \mathrm{P}=0.445)$.

Aquatic invertebrate diversity was also significantly higher at garden sites, but the effect on the aquatic community was more evident in dominant species than rare ones. For aquatic invertebrates, neither species richness nor the Shannon index differed significantly between garden and non-garden sites (Table 1, Figure 4). Simpson's Diversity index values, however, were significantly higher for experimental garden sites $\left(\mathrm{F}_{1,6}=6.440, \mathrm{P}=\right.$ 0.044; Table 1 and Figure 4) than non-garden sites. This difference was primarily attributable to lower dominance of tubificid oligochaetes and gammarid amphipods at experimental garden sites.

Urbanization and anthropogenic activities have greatly increased the levels of nutrients in river systems, especially nitrogen and phosphorus [29,30,31], which can in turn decrease arthropod diversity and abundance $[32,33]$. Many studies have shown that riparian zones act as buffers, moderating anthropogenic impacts on a range of abiotic and biotic stream characteristics [1,34-36], including invertebrate diversity and abundance [37-39]. Because of this, aquatic macroinvertebrate communities are commonly used as indicators of a river system's health, including the riparian zones [40-44]. In the present study, moderate restoration of riparian zones resulted in a significant increase in the diversity of aquatic macroinvertebrates as measured by Simpson's diversity index, demonstrating that enhancing the riparian zone can quickly result in improvements in ecosystem health. Simpson's diversity index is weighted more heavily towards common or dominant species [45], and the higher Simpson's index values for the experimental garden sites resulted primarily from a decreased dominance of pollution-tolerant taxa such as oligochaetes and increased representation of pollution-intolerant taxa such as Ephemeroptera. This result supports the suggestion that pollution and eutrophication often decrease invertebrate diversity by negatively affecting less tolerant taxa [46-48].

Fifty-nine algal genera and 83 infra-generic taxa were identified over the course of the experiment. Chlorophytes and cyanobacteria accounted for ca. $87 \%$ of the total algal biodiversity. Cyanobacteria were the most abundant algae in terms of cell numbers, followed closely by bacillariophytes and chlorophytes. Eugleno-
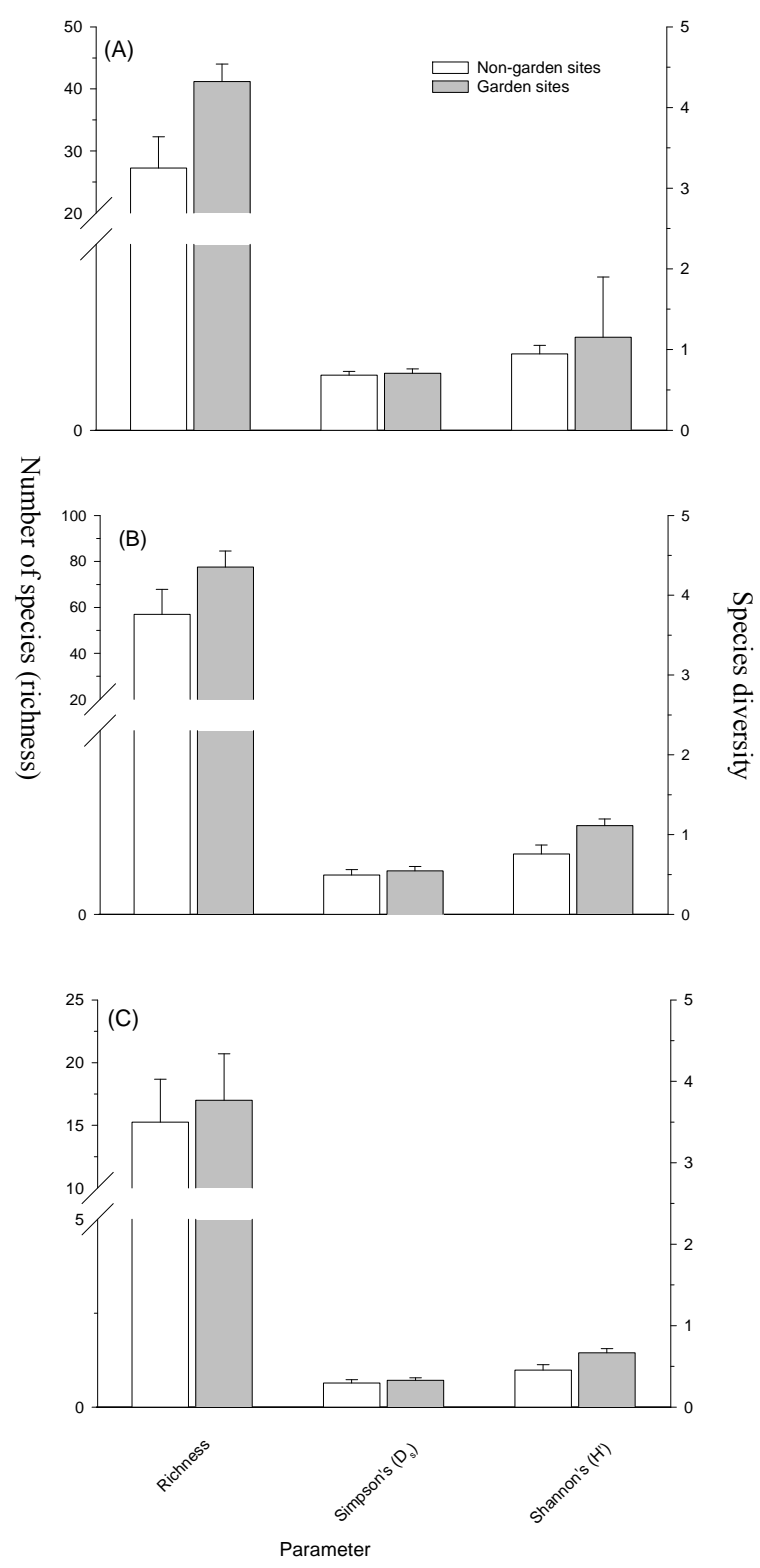

Figure 4. Measures of biodiversity (species richness, $D_{s}$ and H') between garden and non-garden (= control) riparian sites; (A) plants, (B) terrestrial invertebrates, and (C) aquatic invertebrates. Values are mean \pm sem. 
phytes, dinoflagellates and cryptophytes were all only rarely (counted in less than $10 \%$ of samples) encountered. Total biovolume, a more robust measure of the algal community, was typically dominated by chlorophytes, with cyanobacteria accounting for greater than $50 \%$ of the total biovolume in three sites (data not shown). Although garden sites exhibited greater biodiversity at the start and conclusion of the sampling period, these differences were not statistically significant for either diversity index $\left(D_{\mathrm{s}}: \mathrm{F}_{1,7}=2.220, \mathrm{P}=0.180 ; \mathrm{H}^{\prime}: \mathrm{F}_{1,7}=1.698, \mathrm{P}=\right.$ 0.234 ) during the most active portion of the growing season, which resulted in a significant time $\mathrm{x}$ treatment interaction $\left(\mathrm{F}_{7,49}=2.531, \mathrm{P}=0.026\right)$ (Table 2, Figure 5). Further, neither algal cell counts nor biovolume estimates were significantly different between the garden and non-garden sites during the experiment (data not shown). Garden sites did exhibit significantly greater $\left(\mathrm{F}_{1,6}=6.354, \mathrm{P}=0.045\right)$ percent macroalgal cover throughout the 16 months of monitoring (Figure 5).

\subsection{Effects of Riparian Restoration on Ecosystem Function and Plant Recruitment}

We found that even modestly restored riparian plant communities resulted in substantial increases in both terrestrial and aquatic biodiversity while decreasing nutrient loading for small tributaries of the lower St. Johns River. Increased plant biodiversity and the presence of rare species may have resulted from facilitation; this effect may have been enhanced because we purposely utilized plants that varied greatly in size, structure and habitat requirements. For instance, pickerelweed, which is an aquatic emergent species, likely aids in stabilization of the edges of the streambed and increases substrate accumulation around its stems while providing refugia for aquatic invertebrates and juvenile fish. Complementarily, shrub and tree species such as Virginia willow and river birch respectively, which are structurally much more complex and located at higher elevation along the stream banks, likely create microhabitats that have higher degrees of shading, lower temperatures and higher soil moisture. The increase in structural complexity of partially restored riparian communities, results in increased spatial heterogeneity and creates more niches within the overall landscape. Although within-trophic level community composition is a composite of positive (facilitation) and negative (competition) interactions; facilitation has been hypothesized to be more important in stressed or highly disturbed conditions $[49,50]$. Indeed, studies of plant communities have found that colonization of new sites, especially in stress habitats with high levels of light and elevated temperatures, is restricted to shady microhabitats created by the canopy shade of "nurse plants"
[51] or, in the case of stream habitat, emergent species provide stabilization of lotic substrate which reduces mortality for other plants [52]. Our study supports the general contention by Bertness \& Callaway [49] that plant communities in open, sunny, highly disturbed sites (= early successional) are more likely to be influenced by facilitation rather than shaded later successional stages. However, aquatic emergents and shoreline specialists such as pickerelweed and golden Canna respectively are also unlikely to compete strongly with plants at higher elevations along the stream banks (or at most this relationship is likely to be highly asymmetrical. That is, plants at higher elevations may absorb nutrients before they reach emergents and shoreline species, while the latter species are likely to absorb a significant fraction of their nutritional requirements directly from the water).
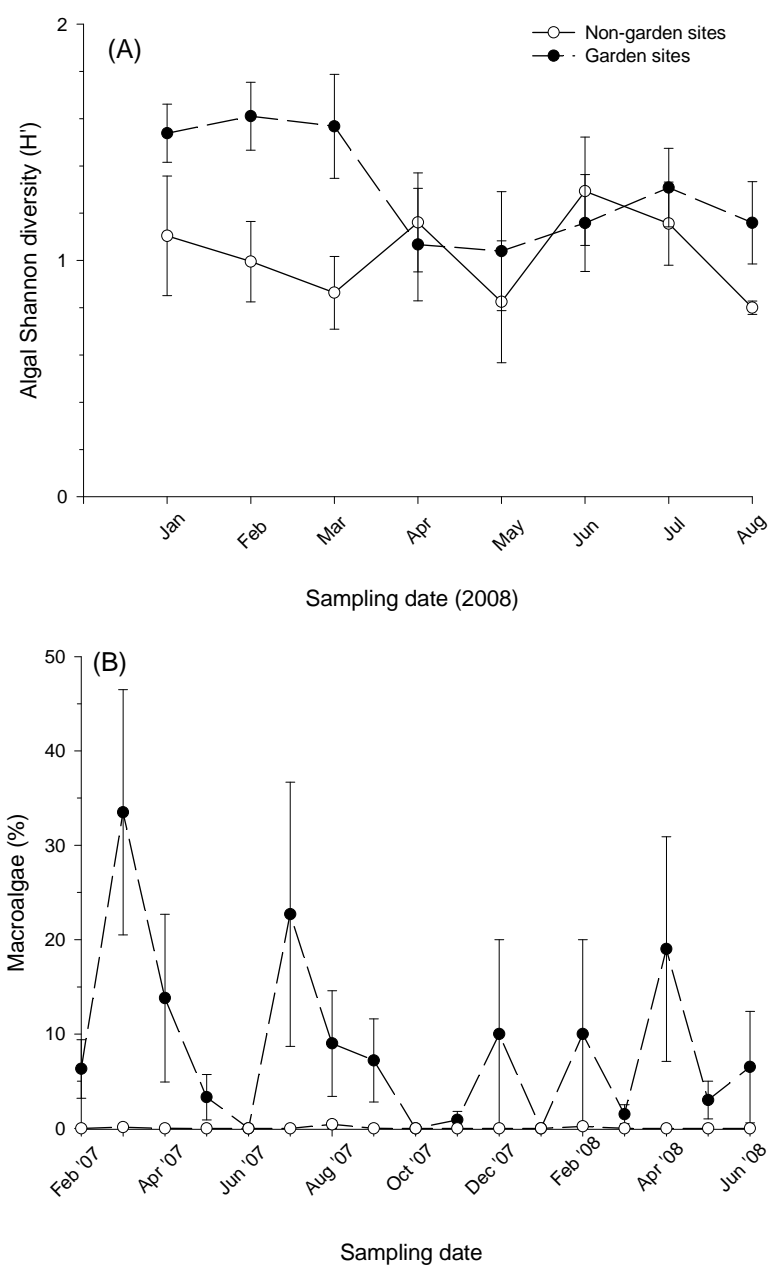

Figure 5. Measures of aquatic algal biodiversity between garden and non-garden (= control) sites; (A) Shannon diversity (H') for cell counts, (B) macroalgae (\%). Values are mean \pm sem. 


\subsection{Assessment Strategies for Riparian Restoration}

Because of the importance of the riparian zone to the stream and entire watershed $[15,18]$, assessments of anthropogenic effects on lotic freshwater systems should include the banks as well. This is especially true if restoration of native vegetation is to be used to ameliorate damaged or disturbed stream ecosystems because the success of this technique depends upon long-term sustainable uptake of nutrients or pollutants while maintaining terrestrial biodiversity and ecosystem function. It has been shown that soil nutrient levels can have strong effects on plant and arthropod community composition [30,53-55], but these effects can be positive or negative. Therefore, terrestrial plant and arthropod community assessments should be conducted in order to determine whether or not native riparian buffer zones would be a viable method for reducing nutrient loading in a stream. In the present study, experimental gardens absorbed more nutrients (nitrogen and phosphorus) than did non-manipulated riparian zones, resulting in an increase in plant and arthropod diversity (species richness and Shannon index values). The increase in arthropod richness resulted primarily from an increase in phytophagous Coleoptera (especially Chrysomelidae and Curculionidae) and Lepidoptera (especially Noctuidae and Papilionidae). This was likely attributable to the concomitant increase in plant species diversity which has been shown in previous studies to affect the diversity of phytophagous insects $[53,56,57]$ and is supported by the strong positive correlation between plant and arthropod diversity measures reported in this study. Interestingly, however, there were also more species of insects with aquatic larval stages, primarily Odonata and Ephemeroptera, at sites with experimental gardens, suggesting increased recruitment of adults for mating and oviposition. It has been suggested that terrestrial arthropods are good indicators of a river system's health [43,58-60]. Therefore, the increase in terrestrial arthropod diversity observed in this study indicates that restoration of native riparian zones not only improves stream ecosystem health, but also improves riparian ecosystem health and may be a viable and sustainable restoration option.

Algae are considered excellent indicators of the health of aquatic ecosystems [61-64] and algal biodiversity, especially that of diatoms, has been correlated with nutrient levels, the presence of contaminants and temporal variability $[65,66]$. In our study, Shannon algal biodiversity within the garden sites was significantly $(\mathrm{p}<0.05)$ greater at the start and end of the monitoring period, but not significantly different during the most active growing season (April through July). While some researchers have also noted that nutrient additions do not necessarily elicit a significant change in algal biodiversity [9], others have reported that confounding factors (such as light limitation, seasonal effects, flow heterogeneity) may mask significant effects of nutrient additions $[67,68]$. In the St. Johns River, changes in lotic algal diversity have been correlated with varying nutrient levels and seasonality over a two-year period [69,70]. Our study, which examined similar factors in smaller tributary streams showed similar trends, but utilized much shallower tributaries and, therefore, was subject to different ecological parameters than previous studies. The percent coverage of macroalgae was also more variable both spatially and temporally in garden sites, while non-garden sites exhibited significantly less visible cover and variability. The majority of the taxa composing macroalgal mats were filamentous greens (e.g., Cladophora, Stigeoclonium and Oedogonium spp.), which is common in low-order, oligo-mesotrophic streams [71]. Macroalgal mats support a diverse epiphytic algal and invertebrate community [72,73], which may account for the aquatic insect community we observed.

\section{Conclusions}

In conclusion, we found that local levels of several key nutrients associated with eutrophication could be significantly reduced over a relatively short time scale $(<$ two years) using relatively small partially restored riparian plant communities along first order tributaries. The experimental design, which incorporated plants native to the area, but which varied substantially in size, structure and habitat preference, also produced other positive benefits including a general increase in plant and invertebrate biodiversity. These results indicate that even modest riparian plant restoration can benefit ecosystem function and this goal may be facilitated by selecting species that maximize structural complexity while minimizing competitive interactions. Our study suggests that an alternating patchwork of partially restored patches among highly disturbed zones in urban areas (which are used by various agencies for tributary access and maintenance) may provide cascading effects; open highly disturbed sites are most likely to benefit from restoration. Future studies will compare the effectiveness of restoring multiple patches along tributaries in an effort to determine whether the trends detected in the current study at the landscape level apply over larger regional scales.

\section{Acknowledgements}

We extend our thanks to thank Mark Hanke for creating the map for the manuscript. In addition, we thank Jamie 
Moon and several undergraduate research assistants for help with the field work. We are also grateful to Richard Wunderlin, Bruce Hansen and John Kunzer of the University of South Florida Herbarium for assistance identifying several plant specimens. This paper is dedicated to Greg Allman (ABB). This study was funded by grants from the St. Johns Water Management District and University of North Florida's Coastal Biology Flagship Program

\section{References}

[1] W. C. Hession, T. E. Johnson, D. F. Charles, D. D. Hart, R. J. Horwitz, D. A. Kreeger, J. E. Pizzuto, D. J. Velinsky, J. D. Newbold, C. Cianfrani, T. Clason, A. M. Compton, N. Coulter, L. Fuselier, B. D. Marshall and J. Reed, "Ecological Benefits of Riparian Restoration in Urban Watersheds: Study Design and Preliminary Results," Environmental Monitoring and Assessment, Vol. 63, No. 1, 2000, pp. 211-222.

[2] T. N. Romanuk and C. D. Levings, "Associations Between Arthropods and the Supralittorial Ecotone: Dependence of Aquatic and Terrestrial Taxa on Riparian Vegetation," Environmental Entomology, Vol. 32, No. 6, 2003, pp. 1343-1353.

[3] W. T. Peterjohn and D. L. Correll, "Nutrient Dynamics in an Agricultural Watershed: Observations on the Role of a Riparian Forest," Ecology, Vol. 65, No. 5, 1984, pp. 1466-1475.

[4] M. D. Matlock, M. E. Matlock, D. E. Storm, M. D. Smolen and W. J. Henley, "Limiting Nutrient Determination in Lotic Ecosystems Using a Quantitative Nutrient Enrichment Periphytometer," Journal of the American Water Resources Association, Vol. 34, No. 5, 1998, pp. 1141-1147.

[5] A. D. Rosemond, P. J. Mulholland and S. H. Brawley, "Seasonally Shifting Limitation of Stream Periphyton: Response of Algal Populations and Assemblage Biomass and Productivity to Variation in Light, Nutrients, and Herbivores," Canadian Journal of Fisheries and Aquatic Science, Vol. 57, No. 1, 2000, pp. 66-75.

[6] S. Sabater, J. Armengol, E. Comas, F. Sabater, I. Urrizalqui and I. Urrutia, "Algal Biomass in a Disturbed Atlantic River: Water Quality Relationships and Environmental Implications," The Science of the Total Environment, Vol. 263, No. 1-3, 2000, pp.185-195.

[7] R. W. Sterner, T. M. Smutka, M. L. McKay, Q. Xiaoming, E. T. Brown and R. M. Sherrell, "Phosphorous and Trace Metal Limitation of Algae and Bacteria in Lake Superior," Limnology and Oceanography, Vol. 49, No. 2, 2004, pp. 495-507.

[8] J. L. Tank and W. K. Dodds, "Nutrient Limitation of Epilithic Epixylic Biofilms in Ten North American Streams," Freshwater Biology, Vol. 48, No. 6, 2003, pp. 1031-1049.

[9] J. L. Greenwood and A. D. Rosemond, "Periphyton Response to Long-Term Nutrient Enrichment in a Shaded
Headwater Stream," Canadian Journal of Fisheries and Aquatic Sciences, Vol. 62, No. 9, 2005, pp. 2033-2045.

[10] M. J. Vanni and J. Temte, "Seasonal Patterns of Grazing and Nutrient Limitation of Phytoplankton in a Eutrophic Lake," Limnology and Oceanography, Vol. 35, No. 3, 1990, pp. 697-709.

[11] J. S. Richardson, P. M. Kiffney, K. A. Maxey and K. Cockle, "An Experimental Study of the Effects of Riparian Management on Communities of Headwater Streams and Riparian Areas in Coastal BC: How Much Protection is Sufficient?" In Sustainable Forest Management Network Conference, Edmonton, Alberta, Canada, 2002, pp. 180-186.

[12] B. W. Sweeney, T. L. Bott, J. K. Jackson, L. A. Kaplan, J. D. Newbold, L. J. Standley, W. C. Hession and R. J. Horwitz, "Riparian Deforestation, Stream Narrowing, and Loss of Stream Ecosystem Services," Proceedings of the National Academy of Sciences, Vol. 101, No. 39, 2004, pp.14132-4137.

[13] S. K. Gregory, F. J. Swanson, W. A. McKee and K. W. Cummings, "An Ecosystem Perspective of Riparian Zones," Bioscience, Vol. 41, No. 8, 1991, pp. 540-551.

[14] M. H. Wahl, H. N. McKellar and T. M. Williams, "Patterns of Nutrient Loading in Forested and Urbanized Coastal Streams," Journal of Experimental Marine Biology and Ecology, Vol. 213, No. 1, 1997, pp. 111-131

[15] S. E. Bunn, P. M. Davies and T. D. Morsisch, "Ecosystem Measures of River Health and their Response to Riparian Catchment Degradation," Freshwater Biology, Vol. 41, No. 2, 1999, pp. 333-345.

[16] S. L. Taylor, S. C. Roberts, C. J. Walsh and B. E. Hatt, "Catchment Urbanisation and Increased Benthic Algal Biomass in Streams: Linking Mechanisms to Management," Freshwater Biology, Vol. 49, No. 6, 2004, pp. 835-851.

[17] K. A. Young, "Riparian Zone Management in the Pacific Northwest: Who's Cutting What?" Environmental Management, Vol. 26, No. 2, 2000, pp. 131-144.

[18] B. M. Renöfält and C. Nilsson, "Landscape Scale Effects of Disturbance on Riparian Vegetation," Freshwater Biology, Vol. 53, No. 11, 2008, pp. 2244-2255.

[19] R. B. Primack, "Essentials of Conservation Biology," 4th Edition, Sinauer Associates, Inc., Sunderland, 1998.

[20] T. F. H. Allen and T. W. Hoekstra, "Problems of Scaling in Restoration Ecology: A Practical Application," In: W. R. Jordan, M. E. Gilpin, and J. D. Aber, Ed., Restoration Ecology: A Synthetic Approach to Ecological Research, Cambridge University Press, Cambridge, 1999, pp. 289299.

[21] W. R. Jordan, G. E. Gilpin and J. D. Aber, "Restoration Ecology: Ecological Restoration as a Technique for Basic Research,” In: W. R. Jordan, M. E. Gilpin and J. D. Aber, Ed., Restoration Ecology: A Synthetic Approach to Ecological Research, Cambridge University Press, Cambridge, 1999, pp. 1-21.

[22] Jacksonville Environmental Protection Agency, "State of the River Report for the Lower St. Johns River Basin, 
Florida: Water Quality, Fisheries, Aquatic Life and Contaminants," 2009.

[23] American Public Health Association, "Standard Methods for the Examination of Water and Wastewater," Donnelly and Sons, Springfield, 1980.

[24] L. Geitler, "Cyanophyceae von Europa," Akademische Presse, Leipzig, Germany, 1932.

[25] G. W. Prescott, "Algae of the Western Great Lake Area," W.B. Brown, Dubuque, 1962.

[26] J. Komárek and K. Anagnosidis, "Susswasser flora von Mitteleuropa, 19/1 Cyanoprokaryota. 1. Teil: Chroococcales," Elsevier Spektrum Akademischer Verlag, Munchen, 1999.

[27] J. Komárek and K. Anagnosidis, "Susswasser flora von Mitteleuropa, 19/2 Cyanoprokaryota. 2. Teil: Oscillatoriales," Elsevier Spektrum Akademischer Verlag, Munchen, 2005.

[28] J. D. Wehr and R. G. Sheath (Eds.), "Freshwater Algae of North America," Elsevier Science, San Diego, 2003.

[29] P. M. Vitousek, J. D. Aber, R. W. Howarth, G. E. Likens, P. A. Matson, D. W. Schindler, W. H. Schlesinger and D. G. Tilman, "Human Alteration of the Global Nitrogen Cycle: Sources and Consequences," Ecological Applications, Vol. 7, No. 3, 1997, pp. 737-750.

[30] V. H. Smith, G. D. Tilman and J. C. Nekola, "Eutrophication: Impacts of Excess Nutrient Inputs on Freshwater, Marine, and Terrestrial Ecosystems," Environmental Pollution, Vol. 100, No. 1-3, 1999, pp. 179-196.

[31] F. A. Fitzpatrick, M. W. Diebel, M. A. Harris, T. L. Arnold, M. A. Lutz and K. D. Richards, "Effects of Urbanization on Geomorphology, Habitat, Hydrology, and Fish Index of Biointegrity of Streams in the Chicago Area, Illinois and Wisconsin," In: L. R. Browns, R. H. Gray, R. M. Hughes and M. R. Meador, Ed., Effects of Urbanization on Stream Ecosystems. American Fisheries Society, Symposium 47, Bethesda, 2005. pp. 87-115.

[32] R. Pyle, M. Bentzien and P. Opler, "Insect Conservation," Annual Review of Entomology, Vol. 26, No. 1, 1981, pp. 233-258.

[33] N. E. McIntyre, "Ecology of Urban Arthropods: A Review and a Call to Action," Annals of the Entomological Society of America, Vol. 93, No. 4, 2000, pp. 825-835.

[34] K. W. Cummins, "Structure and Function of Stream Ecosystems," Bioscience, Vol. 24, No. 11, 1974, pp. 631-641.

[35] P. J. Muholland, "Regulation of Nutrient Concentrations in a Temperate Forest Stream: Roles of Upland, Riparian and Instream Processes," Limnology and Oceanography, Vol. 33, No. 7, 1992, pp. 1512-1526.

[36] S. C. Trombulak and C. A. Frissell, "Review of Ecological Effects of Roads on Terrestrial and Aquatic Communities," Conservation Biology, Vol. 14, No. 1, 2000, pp. 18-30.

[37] J. M. Quinn, I. K. G. Boothroyd and B. J. Smith, "Riparian Buffers Mitigate Effects of Pine Plantation Logging on New Zealand Streams: 2. Invertebrate Communities," Forest Ecology and Management, Vol. 191, No. 1-3, 2004, pp.129-146.
[38] A. R. Danger and B. J. Robson, "The Effects of Land Use on Leaf-Litter Processing by Macroinvertebrates in an Australian Temperate Coastal Stream," Aquatic Sciences, Vol. 66, No. 3, 2004, pp. 296-304.

[39] D. E. Wooster and S. J. DeBano, "Effect of Woody Riparian Patches in Croplands on Stream Macroinvertebrates," Archiv fur Hydrobiologie, Vol. 165, No. 2, 2006, pp. 241-268.

[40] D. M. Rosenberg and V. Resh, "Freshwater Biomonitoring and Benthic Macroinvertebrates," In: D. M. Rosenberg and V. H. Resh, Ed., Freshwater Biomonitoring and Benthic Macroinvertebrates, Chapman and Hall, New York, 1993, pp. 1-9.

[41] J. G. Kennen, "Relation of Macroinvertebrates Community Impairment to Catchment Characteristic in New Jersey Streams," Journal of the American Water Resources Association, Vol. 35, No. 4, 1999, pp. 939-955.

[42] V. H. Resh, M. J. Myers and M. J. Hannaford, "Macroinvertebrates as Biotic Indicators of Environmental Quality," In: F. R. Hauer and G. A. Lamberti, Ed., Methods in Stream Ecology, Academic Press, San Diego, 1996, pp. 646-667.

[43] D. N. Kimberling, J. R. Karr and L. S. Fore, "Measuring Human Disturbance Using Terrestrial Invertebrates in the Shrub-Steppe of Eastern Washington (USA)," Ecological Indicators, Vol. 1, No. 2, 2001, pp. 63-81.

[44] A. P. Covich, M. C. Austen, F. Bärlocher, E. Chauvet, B. J. Cardinale, C. L. Biles, P. Inchausti, O. Dangles, M. Solan, M. O. Gessner, B. Statzner and B. Moss, "The Role of Biodiversity in the Functioning of Freshwater and Marine Benthic Ecosystems," Bioscience., Vol. 54, No. 8, 2004, pp. 767-775.

[45] A. E. Magurran, "Measuring Biological Diversity," Wiley-Blackwell, Hoboken, 2004.

[46] H. L. Garie and A. McIntosh, "Distribution of Benthic Macroinvertebrates in a Stream Exposed to Urban Runoff," Water Resources Bulletin, Vol. 22, No. 3, 1986, pp. 447-455

[47] C. Rawer-Jost, J. Bohmer, J. Blank and H. Rahmann, "Macroinvertebrate Functional Feeding Group Methods in Ecological Assessment," Hydrobiologia, Vol. 422-423, No. 0, 2000, pp. 225-232.

[48] M. J. Paul and J. L. Meyer, "Streams in the Urban Landscape," Annual Review of Ecology and Systematics, Vol. 32, 2001, pp. 333-365.

[49] M. D. Bertness and R. Callaway, "Positive Interactions in Communities: A Post Cold War Perspective," Trends in Ecology and Evolution, Vol. 9, No. 5, 1994, pp. 191-193.

[50] M. D. Bertness and G. H. Leonard, "The Role of Positive Interactions in Communities: Lessons from Intertidal Habitats," Ecology, Vol. 78, No. 7, pp. 1976-1989.

[51] M. Holmgren, M. Scheffer and M. A. Huston, "The Interplay of Facilitation and Competition in Plant Communities," Ecology, Vol. 78, No. 7, 1997, pp. 1966-1975

[52] J. M. Levine, "Complex Interactions in a Streamside Plant Community," Ecology, Vol. 81, No. 12, pp. 3431-3444.

[53] E. Siemann, "Experimental Tests of Effects of Plant Pro- 
ductivity and Diversity on Grassland Arthropod Diversity," Ecology, Vol. 79, No. 6, 1998, pp. 2057-2070.

[54] L. Gough, C. W. Osenberg, K. L. Gross and S. L. Collins, "Fertilization Effects on Species Density and Primary Productivity in Herbaceous Plant Communities," Oikos, Vol. 89, No. 3, 2000, pp. 428-439.

[55] N. M. Haddad, J. Haarstad and D. Tilman, "The Effects of Long Term Nitrogen Loading on Grassland Insect Communities," Oecologia, Vol. 124, No. 1, 2000, pp. 7384.

[56] E. Siemann, D. Tilman, J. Haarstad and M. Ritchie, "Experimental Tests of the Dependence of Arthropod Diversity on Plant Diversity," American Naturalist, Vol. 152, No. 5, 1998, pp. 738-750.

[57] J. Koricheva, C. P. H. Mulder, B. Schmid, J. Joshi and K. Huss-Danell, "Numerical Responses of Different Trophic Groups of Invertebrates to Manipulations of Plant Diversity in Grasslands," Oecologia, Vol. 125, No. 2, 2000, pp. 271-282.

[58] R. H. L. Disney, "Assessments Using Invertebrates: Posing the Problem," In: M. B. Usher, Ed., Wildlife Conservation Evaluation, Chapman and Hall, London, 1986, pp. 272-293.

[59] D. M. Rosenberg, H. V. Danks and D. M. Lehmkuhl, "Importance of Insects in Environmental Impact Assessment," Environmental Management, Vol. 10, No. 6, 1986, pp.773-783

[60] C. Kremen, R. K. Colwell, T. L. Erwin, D. D. Murphy, R. F. Noss and M. A. Sanjayan, "Terrestrial Arthropod Assemblages: Their Use in Conservation Planning," Conservation Biology, Vol. 7, No. 4, 1993, pp. 796-808.

[61] P. V. McCormick and J. Cairns, "Algae as Indicators of Environmental Change," Journal of Applied Phycology, Vol. 6, No. 5-6, 1994, pp. 509-526.

[62] R. G. Verb and M. L. Vis, "Comparison of Benthic Diatom Assemblages from Streams Draining Abandoned and Reclaimed Coal Mines and Nonimpacted Sites," Journal of the North American Benthological Society, Vol. 19, No. 2, 2000, pp. 274-288.

[63] S. S. Dixit, "Diatoms: Powerful Indicators of Environmental Change," Environmental Science and Technology, Vol. 26, No. 1, 1992, pp. 23-33.
[64] J. T. Zalack, D. A. Casamatta, R. G. Verb and M. S. Vis, "A Two-Year Study of the Algal Community in a Woodland Stream from Southeastern Ohio," Northeastern Naturalist, Vol. 13, No. 3, 2006, pp. 301-318.

[65] I. Lavoie, S. Campeau, F. Darchambeau, G. Cabana and P. J. Dillion, "Are Diatoms Good Indicators of Temporal Variability in Stream Water Quality?" Freshwater Biology, Vol. 53, No. 4, 2008, pp. 827-841.

[66] S. N. Francoeur, B. J. F. Biggs, R. A. Smith and R. L. Lowe, "Nutrient Limitation of Algal Biomass Accrual in Streams: Seasonal Patterns and a Comparison of Methods," Journal of the North American Benthological Society, Vol. 18, No. 2, 1999, pp. 242-260.

[67] H. Gausch and S. Sabater, "Seasonal Variation in Photosynthesis-Irradiance Responses of Biofilms in Mediterranean Streams," Journal of Phycology, Vol. 31, No. 5, 1995, pp. 727-735.

[68] A. J. Veraart, A. M. Romani, E. Tornes and S. Sabater, "Algal Response to Nutrient Enrichment in a Forested Oligotrophic Stream," Journal of Phycology, Vol. 44, No. 3, 2008, pp. 564-572.

[69] A. E. Dunn, "Experimental Manipulation of Nitrogen and Phosphorous Nutrient Amendments and Observations of the In Situ Epiphytic Algal Community from the Lower St. Johns River (Florida) throughout a Growing Season," M. S. Thesis, University of North Florida, Jacksonville, 2007

[70] A. E. Dunn, D. R. Dobberfuhl and D. A. Casamatta, "A Survey of Algal Epiphytes from Vallisneria Americana Michx. (Hydrocharitaceae) in the Lower St. Johns River, Floirda," Southeastern Naturalist, Vol. 7, No. 2, 2008, pp. 229-244.

[71] B. J. F. Biggs, "Patterns in Benthic Algae of Streams," In: R. J. Stevenson, M. L. Bothwell and R.L. Lowe, Eds,. Algal Ecology, 1996, Academic Press, New York, pp. 3156.

[72] W. K. Dodds and D. A. Grudder, "The Ecology of Cladophora," Journal of Phycology, Vol. 28, No. 4, 1992, pp. 415427.

[73] H. Hillebrand, M. Kahlert, A. Haglund, U. Berninger, S. Nagel and S. Wickham, "Control of Microbenthic Communities by Grazing and Nutrient Supply," Ecology, Vol. 83, No. 8, 2002, pp. 2205-2219. 